\title{
The creation and critique of a Central African myth *
}

\author{
par \\ WILLIAM J. SAMARIN **
}

M. Diki-Dikiri a exposé en français une théorie opposée à la mienne (publiée en anglais) sur l'origine du sango, langue véhiculaire et officielle de la République centrafricaine. Je qualifie l'essai de mon collègue de mythique (au sens anthropologique) parce qu'il est motivé par des considérations idéologiques davantage que par des arguments historiques. Pour moi, le sango est le résultat de la pidginisation des dialectes locaux du ngbandi sur le Haut-Oubangui au tout début de la colonisation en 1887. M. Diki-Dikiri affirme au contraire qu'il était déjà une langue véhiculaire du nom de dendi avant l'arrivée des Européens; les changements au cours de l'évolution de la langue s'expliquent sans pidginisation. Je réfute ici et point par point l'argumentation de mon collègue.

Mots clés: sango, colonisation, République centrafricaine, mythologie politique, langue véhiculaire, pidginisation.

In opposition to my reconstruction of the origin of Sango - the lingua franca and official language of the Central African Republic - is that of M. Diki-Kidiri. His I characterize as mythic, motivated by ideology and not grounded on historic and linguistic facts. Whereas I have argued that Sango emerged because of the pidginization of Ngbandi dialects at the very beginning of the colonization of the region, Diki-Kidiri alleges that it simply evolved from Dendi, already a vehicular language when Europeans arrived. His arguments are submitted to analysis and contradiction by thorough documentation.

Key words : sango, colonization, Central African Republic, political mythology, lingua franca, pidginization.

* Several small and large grants made possible research on the origin of Sango, starting with one in 1972 from the American Philosophical Society and another from the International Studies Program of the University of Toronto. A period of research in France was also made possible by the Centre national de la recherche scientifique (CNRS). Large grants came from the Conseil de recherches en sciences humaines du Canada. Help was given by so many individuals that I cannot possibly list them here.

** Professeur émérite, Département d'anthropologie, Université de Toronto, Ontario, $<$ w.samarin@utoronto.ca>. 
Given the circumstances in which they arise, pidgins challenge the intelligence and patience of those who attempt to reconstruct their origins ${ }^{1}$ Sango - since independence the langue nationale of the Central African Republic but made to share the role that French alone had had as langue officielle by former President André Kolingba - is no exception.

My explanation for the origin of this new language, while not yet given in full detail, has been alluded to and adumbrated in several publications (Samarin 1982a, 1982b, 1984a, 1984b, 1984-1985, 1985, 1986, 1988, 1989a, 1989b). Sango, I seek to demonstrate, must have begun to emerge as a new language through the pidginization of the local Ngbandi dialects on the upper Ubangi river when Alphonse Van Gele, a representative of the État indépendant du Congo (EIC, or Congo Free State), remained more than a year with his ethnolinguistically diverse African auxiliaries (see below). The pidgin seems to have become stabilized very quickly. In any case, its existence was noted as early as 1896 (see below; for the year 1892 see fn 30). There are lists of words from 1906 and 1908, and a grammar of 1911. By 1925 the language was already found in the west, near the Cameroun border, far from its place of birth (Allégret 1987).

A very different account of Sango's history is that of M. Diki-Kidiri ${ }^{2}$. The following nine assertions, although in my own words, reflect to the best of my understanding Diki-Kidiri's views, and indeed have have been edited by him (correspondence from 10 to 28 November 1996; material within quotations marks are his own emmendations in English). My critique follows the exposition.

I would like to suggest that the alleged history of Sango is not credible and convincing; indeed, it seems to be mythic in the technical sense. The myth is in fact encapsulated in the following pronouncement: "Ainsi se forme, sous nos yeux une nouvelle intégration des ethnies centrafricaines pour donner naissance à une nouvelle nation: la nation centrafricaine dè demain, caractérisée d'ores et déjà par une langue maternelle: le sango" (Diki-Kidiri [henceforth DK] 1986:92-93).

1. Note the prolonged debate over whether French creoles have pidgins in their ancestries, the most recent statement being Baker 1996, a review of Chaudenson 1992.

2. Diki-Kidiri is a Central African employed as chargé de recherches with the CNRS in the laboratoire LLACAN (Langage, Langues et Cultures d'Afrique noire), previously Laboratoire des langues et civilisations à tradition orale (LACITO, LP 3-121). 
THE MYTH RECONSTRUCTED ${ }^{3}$

Sango - originally known as Dendi - was a commercial [i.e., trade] and vehicular language [i.e., lingua franca] before the arrival of Europeans at the end of the nineteenth century. It became a lingua franca because the Dendi people served as intermediaries between others in their region. The lingua franca was used throughout the Ubangi basin at least as far as Bangui long before colonization. Therefore we must conclude that neither the local Ngbandi nor the expatriate participants of colonization -Europeans and Africans-played any role in the creation of the lingua franca. Among other reasons, if whites were responsible for it, they would have said so. As vehicular Dendi began to be used by others, it changed. The linguistic changes are explained in four ways. a) Foreigners were responsible for the language's simplification. b) Central Africans were responsible for the alteration of Ngbandi, leading to the birth of "Dendi". c) The language's expansion led to changes. d) Interaction with the Ngbugu and the Nzakara led to the alterations. Very quickly the language spread throughout the hinterland of Haut-Oubangui. Finally, Sango, in its present form, is neither a pidgin nor a creole.

1. Sango -originally known as Dendi-was a commercial [i.e., trade] and vehicular language [i.e., lingua franca] before the arrival of Europeans at the end of the nineteenth century (DK 1986:87) ${ }^{4}$. However, this claim is made in several and sometimes inconsistent ways. For example:

- "Sango ['langue véhiculaire, langue commerciale'] [...] s'est développé à partir du sango- yakoma, langue des Sango et des Yakoma." (DK 1977:717; cf. $1979 \mathrm{~b}: 33 ; 1981: 29 ; 1985 \mathrm{a}: 39)$

- “... le sango était l'une des huit langues qui se parlaient, de bief en bief, le long [de l'Oubangui] [...]" (DK 1985a:77).

- "[...] une forme de sango servait déjà de langue véhiculaire entre les ethnies riveraines depuis le village des Abira jusqu’à Bangui [...]” (DK 1985a:39) ${ }^{5}$.

3. For the sake of exposition and elegance, this summary aims at being a discursive text rather than a mere compilation of the claims that are numbered below. Only the latter should be taken as carefully representing the alleged history of Sango.

4. Earlier than this I made a similar unfounded and therefore erroneous suggestion (Samarin 1967:i): "It is not yet clear precisely when and why Sango came to be used as a contact language, but it appears that when the French conquered this Ubangi-Shari area the riverine population was already using it." I understand lingua franca and langue véhiculaire (vehicular language) to refer to the same thing and commercial language and trade language also to mean the same thing.

5. This is a curious statement, since at this place the inhabitants were with one exception (Donnay 1896, discussed below) called Yakoma. If the Dendi language was a lingua franca, the area where it was used must surely comprehend all of that where the so-called Dendi lived. In the early documents this French post is spelled Abiras, found to the west of the mouth of Mbomu river at its confluence with the Ubangi, opposite that of the État indépendant du Congo (EIC) at Yakoma (e.g., Colrat de Montrozier 1902). 
- "la langue véhiculaire dendi a dû servir, le long du cours moyen de l'Oubangui que contrôlaient les Ngbandi, comme langue de marché et d'échange avec les populations banda [...] qui bordent l'arrière-pays." (DK 1986:85-86).

This assertion is based, as the author recognizes, on a single statement published by a French officer who in 1898 had gone up the Mbomu river on his way to the Sudan in what was called the Nile Expedition ${ }^{6}$.

C'est le Dendi qui a donné son nom à la langue qui se parle tout le long de l'Oubangui et qui est une sorte de volapük?. Toutes ces races de pagayeurs, toujours en pirogues, par suite en relations constantes, ont, à vrai dire, à peu près la même langue, encore y a-t-il quelques différences, et pour plus de commodité ces primitifs ont realisé ce que nous autres civilisés nous n'avons pu encore faire. Avec les mots communs à tous, peut-être en en modifiant quelques-uns et en en créant de nouveaux, ils ont fabriqué les [sic] Dendi dont la simplicité est telle que nos tirailleurs et nous, nous arrivons à nous faire comprendre de nos pagayeurs. Assurément, je ne proposerai pas le Dendi comme langue universelle et commercial, nous la trouverions, nous hommes compliqués, un peu pauvre de mots et je crois que nous nous résoudrions difficilement à dire: "Niama kota kota: la viande grosse grosse" pour désigner un éléphant, et "Niama kétékété: la viande petite petite" pour représenter un moustique, en joignant à ces mots une mimique toute spéciale qui aide à la compréhension (Baratier n.d.:28, italics added) ${ }^{8}$.

The statement is an important witness, it is claimed, because Baratier was one of "les premiers Européens à venir dans le pays par le fleuve" (DK 1981:31). Baratier's statement is "Ie plus ancien témoignage que nous ayons sur le sango véhiculaire" (DK 1981:35; cf. 1986:85). This assertion has been made by him in different forms. Thus:

6. By attributing 1898 as the year of publication to this work one seems to suggest that the events recounted by Baratier were fresh in his mind, but the cover of the copy I consulted in France identifies the author as general, a rank acquired after 1898, and the Library of Congress in Washington, D.C. suggests 1910 as the date of publication; elsewhere I find 1912.

7. See below for an earlier citation than this one. The word volapuk seems to be used in a derogatory manner, possibly because an artificial language by the name Volapuk (vol 'world' $+p u k$ 'language') was created in 1880 by a German, J. M. Schleyer, as an international auxiliary language, popular already in France by 1885 .

8. There is another and possibly earlier such declaration: “[...] les relations s'établissent entre toutes les tribus voisines dans le Haut-Oubanghi, grâce à un sabir spécial, le dendi" (Girard 1901:85). I can add another reference for the "langue Dendi": On 31 December 1900 the commandant at Mobaye reported that the people in his administrative circle were being afflicted with smallpox, adding "yamba [actually yàngbà] en langue Dendi." However, I do not think that one is obliged to take this citation as evidence for the existence of the alleged "Dendi vehicular language' - a language, that is, different in a significant way from the language of the people being administered. Since this is a report of a local epidemic the commandant must have been referring to the local people, those who subsequently acquired the name Sango. It is quite possible that one of his African assistants told him that this is what the Dendi called the disease, not knowing that the very people among whom they were living also called it that. Other equally reasonable explanations or readings can be given of this colonial report. A Musette, commandant du cercle, Cercle de Mobaye, Mobaye (ANX [Archives nationales, Archives du Gouvernement général de l'Afrique equatoriale française, Aix-en-Provence] 4[3]D8). 
- "le sango, sous 1'appellation 'dendi', était déjà une langue véhiculaire avant l'arrivée des Européens dans le pays" (DK 1981:35, 39; cf. 1982:831; 1985a:39; $1986: 87 ; 1992: 23)^{9}$.

- It is wrong to impute the "naissance" of the vehicular language to the Ngbandi, [...] (DK 1986:88) ${ }^{10}$.

2. Dendi became a lingua franca because the Dendi people served as intermediaries in their region. The Dendi are identified as people (numbering less than 50,000, but see below for a lower estimate) living in a restricted area along the Mbomu, who speak a variety of Ngbandi (DK 1979a:36; 1979b) ${ }^{11}$. They were intermediaries between Ngbugu (who speak a variety of Banda) and Nzakara peoples (DK 1986:85).

3. The lingua franca was used by riverine people all along the Ubangi river at least as far as Bangui. Because the Dendi were excellent canoers, like the other Ngbandi of the region - namely, Yakoma and Sango, as they came to be called- the Dendi vehicular language must have served ("a dû servir") as a market and trade ("échange") language for the people living along the middle Ubangi river and with the Banda groups that lived inland the length of the river (DK 1986:85-86) ${ }^{12}$. But the qualification "must have served" is removed when it is observed that the vehicular language was used "le long du cours moyen de l'Oubangui" (DK 1986:85) or even "le long de la rivière Oubangui" (DK 1992:23) at the end of the 19th century, where it was a "langue véhiculaire et

9. Note the use of quotation marks with the name of the language. Although Diki-Kidiri argues that the vehicular language took off from and is but an extension of the vernacular called Dendi, he insinuates a change by adding quotation marks, whose significance is ambiguous.

10. But elsewhere we learn that Sango issued both from Ngbandi (DK 1987b:113) and from the "parlers riverains" (Boyeldieu \& Diki-Kidiri 1988:32; interchangeable apparently with "parlers ngbandi" [DK 1987b] and "parlers yakoma" [DK 1982:81]).

11. From this history one would have to infer that the Dendi language somehow acquired a different name when it became an extra-territorial lingua franca, while remaining the same language. This is exactly the conclusion a bibliographer drew in writing an annotation of one of the accounts of Sango's spread (DK 1979a): "Cet article tente d'analyser les facteurs sociologiques et psychologiques qui ont favorisé l'essor du sango, langue qui, au départ, n'était qu'un petit dialecte ngbandi fort localise" (Denyse de Saivre in Bourdin et al. 1983: 210). In other words, the spread of Sango as a lingua franca is being treated as if it were a lingua franca just like Hausa, Fulani, or English-with a significant difference that is discussed below. Compare: "La langue véhiculaire échangea progressivement le nom de 'dendi' contre celui de 'sango' qui lui resta définitivement depuis l'institution de Bangui comme capitale [...] en 1906" (DK 1987a :103).

12. On the other hand, it is said that Baratier's statement-"Dendi [...] se parle tout le long de l'Oubangui"-should certainly not be taken "à la lettre" (DK 1981:35). What provoked the precolonial expansion of Sango remains, Diki-Kidiri says, a complete mystery (DK 1979a:37; see also 1981:40). Research, he says, needs to be undertaken to explain why Dendi spread along the Ubangi river and was learned by the Gbanziri (DK 1981:40). He also seems to believe that there were other lingua francas in the area. When Baratier refers to "le Dendi", he is talking about a specific vehicular language, and when he writes "les Dendi", Diki-Kidiri interprets, "il réfère explicitement à plusieures langues véhiculaires [...]" (DK 1981:35). I believe, however, that "les Dendi" was a typographical error for "le Dendi." 
certainement commerciale" (DK 1981:39; 1992:23), but only as far as Bangui (DK 1981:35).

4. The Ngbandi -or those who "eventually came to be known as Yakoma and Sango on the Ubangi river"-- and expatriate participants of colonization did not have a role in the creation of the lingua franca. Pains are taken to deny that Ngbandi (and by implication, "Dendi") was spread by the French and that this claim, made by certain persons, is without foundation and is contradicted by "les documents d'époque" (DK 1981:34) ${ }^{13}$. For reasons that are not clear much is made of the fact that it was the Gbanziri who were "les premiers dans le Bas-Oubangui, à accueillir véritablement les Européens, et à les servir ..." (DK 1981:34; see also pp. 31, 32, 35). While this is true (and fully discussed in Samarin 1989:142ff), the fact does not support Diki-Kidiri's argument, but only obfuscates it.

Up to this point, we must conclude, the roles of (1) the Dendi language, (2) the 'Dendi' vehicular language, and (3) the Dendi people have not been made clear.

5. If whites were responsible for the creation of the vehicular language, they would have said so. Diki-Kidiri claims evidence of a negative kind for his hypothesis in saying, "Si les Blancs étaient à l'origine de la formation du sango véhiculaire, il n'aurait pas manqué de le souligner copieusement" (DK 1981:36). Since this kind of assertion is ill-considered in historiography, it can be dismissed as speculative. In any case, as we see below, whites were not directly responsible for the fabrication of Sango.

6. As vehicular Dendi began to be used by others, it changed. Indeed, Sango changed so much that the other Ngbandi-speaking peoples look down on the Dendi (DK 1986:85). Although Diki-Kidiri never to my knowledge considers Sango a pidgin nor postulates a pidgin in its history, he is obliged to deal with changes that a linguistic specialist of language contact would consider the consequences of pidginization. (a) He begins by denying that Dendi was as simple as Baratier said it was (see above; DK 1981:38), saying that it could be considered a pidgin only if it was characterized by a "pauvreté remarkable", implying that the lingua franca was not 'remarkably poor' (DK 1981:36, 37), providing, however, no evidence to the contrary.

It must be noted that the argumentation is based on logic, not on historical facts. It is said, for example, that “... le pidgin ne peut durer longtemps qu'en

13. The word 'expansion' used in the preceding footnote is faithful to Diki-Kidiri's terminology. In his history the role of the Ngbandi appears to be contradictory. On the one hand, he categorically attributes its ancestry (which is my term here) to the Dendi and denies any role to the (other) Ngbandi (DK 1987a:103; 1986:87, 88); elsewhere he does: "[il] s'est développé à partir de la langue ngbandi" (DK 1981:29; cf. p. 31, 32; see also DK 1987b:113). 
subissant une profonde transformation dans le sens d'un enrichissement" (DK 1981:38). It is more "vraisemblable" to suppose that 'Dendi' was a commercial language before the arrival of Europeans than to assume that this [alleged] 'pidgin Dendi' [his quotes] made "gigantic" progress in ten years (i.e., 18971906) (DK 1981:38), implying that by the latter date Sango was as rich as any other language ${ }^{14}$. Assuming, however, that there was a 'pidgin Dendi' of the explorers, he says, one of two things could have happened to it. One: "[il] a ... disparu avec eux", i.e., when whites left the area 15. Two: it was "intégré [dans] la langue véhiculaire qui l'a précédé" as the Europeans came to know the latter better (DK 1981:38). (Presumably this would simply mean that a pidginized or even jargonized form of 'Dendi' — not a pidgin - was replaced by good Dendi.) But on the page just cited we read that whatever had been the vehicular language's "richesse" or "pauvreté réelle" in 1897, it would have been "transformed" by the following: new objects, new needs, and new social structures. In other words, we are given two contradictory processes by which the vehicular language would have been rehabilitated. For further discussion see (11) below.

The linguistic changes in Sango are explained in four ways. (This being a historical rather than linguistic essay, the discussion is abbreviated.) (a) Foreigners (i.e., "all non- Ngbandi people") are responsible for the vehicular language's simplification. When foreigners began to speak 'Dendi' (i.e., the vehicular language), they contributed both to its impoverishment ("appauvrir") and its enrichment ("enrichir") (DK 1981:41; cf 1986:89). (b) Central Africans (i.e., the "indigenous riverside people") were responsible for the alteration of Ngbandi, leading to the birth of 'Dendi.' "Ce contact permanent avec les Ngbougou et les Nzakara entraina l'altération de la langue ngbandi qu'utilisent les Dendi, et donna naissance à un parler véhiculaire nommé 'dendi'" (DK $1986: 85)^{16}$. (c) It was the language's expansion that led to changes. "En raison de son expansion son vocabulaire s'est constamment transformé et sa syntaxe a développé des traits propres", which differentiate it from other Ngbandi "parlers", especially vernacular Sango (DK 1987b:113; cf. 1981:40;

14. The years comprehending the ten-year period are not given. Elsewhere we are informed that in 1906 and 1911 Sango was already considered a commercial language (DK 1981:38). The assertion is a very puzzling one in any case, given the fact that even today Sango is extremely simple by comparison with all other Ubangian languages. It would make sense only if the word pidgin refers to something that could hardly be called a language at all.

15. This is a puzzling statement, since the French did not begin to leave the area until after independence.

16. Elsewhere the word naissance is studiously avoided in discussing Sango's history. Thus: If Éboué had known the histories [sic] of the people of the Haut-Oubangui, "il lui aurait suffit d'utiliser [...] le mot 'essor' à la place de 'naissance' pour être totalement conforme à la réalité historique [...]" (DK 1986:87, italics added by me). 
1986:86; 1987:103) ${ }^{17}$. (d) It was interaction with the Ngbugu and the Nzakara that led to initial alterations. "... Ce contact permanent avec les Ngbougou et les Nzakara entraîna l'altération de la langue ngbandi qu'utilisent les Dendi, [...]" (DK 1986:85) ${ }^{18}$.

7. The vehicular language spread very quickly throughout the HautOubangui. To reinforce the argument that Sango is a truly indigenous and autonomous phenomenon, emphasis is placed on its rapid but unexplainable expansion. Thus: "L'expansion du sango [presumably that which had been called 'Dendi'] en Centrafrique n'a cessé d'étonner ceux qui l'étudient [...]" (DK 1981:29; cf. 1987:113). While saying "Les origines à cette expansion sont encore à chercher" (DK 1981:40; 1986:91), two factors are rejected: colonization and education. It is, we are informed, "erroné" to attempt to explain Sango's expansion by claiming that the Ngbandi were "les premiers employés des premiers Français" [as does Kêrux] (1981:34). And "la langue véhiculaire sango" did not spread into the interior through the "enseignement scolaire" (DK 1986: 89). However, no attempt is made to explain why Ngbandi (or 'Dendi', Sango, or the "langue véhiculaire") became - as it is claimed- the vehicular language "at least" as far as Bangui ${ }^{19}$.

8. Sango is not a pidgin. This is not a statement Diki-Kidi has ever expressed in print - to my knowledge at least, but his published statements lead to no other conclusion. The word pidgin does occur on a few occasions in his publications, as in "L'expansion du sango en Centrafrique" (DK 1981), where, under the heading "Analyse critique de "l'hypothèse Samarin", he gives two characterizations of pidgins. The first has no relevance to Sango or to me, because the word pidgin is used for "une langue véhiculaire issue de l'anglais"

17. The word développement is used elsewhere in a context of writing about its promotion and modernization since independence (DK 1992:24). Compare the quoted statement with the following: "Because of this use [as a lingua franca] it was very much simplified and to some extent transformed in structure" (Samarin 1967:17).

18. Compare with the following: "Les Dendi parlent Également un ngbandi mais leur vocabulaire emprunte aux dialectes voisins dans une proportion considérable, la prononciation est également différente" (Dampierre 1967:88). But after citing this passage, Boyeldieu-who maintains that the Ngbandi group is "very homogenous"-recognizes that the Dendi of Ouango, studied by him, might be different from that of Bangassou, which is closer to the homeland of speakers of Nzakara (Boyeldieu 1982:16, 17). Boyeldieu, in my opinion, is being diffident to a fault. After all, the two towns are only about thirty-five or a little over fifty $\mathrm{km}$ apart in my estimation-by river in the first case and by land in a straight line in the second-and both are located on the bank of the Mbomu river. Except for the Chutes Hanssens very near Ouango, there is only one set of rapides between the two towns. It is possible, therefore, that Dampierre's statement is accurate only for the Dendi who were his assistants. Bangassou was an important administrative and commercial center in the region.

19. An opinion was expressed on this subject by one of the early and much-published colons, Georges Bruel. See (1) below for quotation and discussion. 
(p. 37) ${ }^{20}$. The second is one with which I am explicitly associated. He alleges of Robert A. Hall, Jr. and me that

lorsqu'une langue —n'importe laquelle - vient à subir (1) une réduction brutale de son vocabulaire, (2) une simplification excessive de sa structure syntaxique, et (3) une forte limitation de ses domaines d'emploi (autrement dit ses fonctions sociales), elle est conforme à la définition d'un pidgin (DK 1981:37) ${ }^{21}$.

With this set of criteria for identifying what could be called a pidgin -whether they were erroneous or not- Diki-Kidiri might have argued that Sango is not a pidgin, because (1) there never was a brutal reduction in its vocabulary, (2) its syntactic structure was not simplified, and (3) its functions were never reduced by comparison to those of other Central African languages. Because he never has, one is led to accept the thesis that Sango never was and never had a pidgin in its ancestry (see also DK 1986).

9. Sango is not a creole. Sango is not a creole for three reasons: because it has no pidgin in its history, because its origins are unknown, and because it does not have a community of native speakers (DK 1981:31, 39, 40) 22 .

\section{CRITIQUE OF THE MYTH}

Although based on a few fragments of truth, Diki-Kidiri's account of the history of Sango in the Central African Republic cannot stand up to criticism. The following, while not being a complete history of the origin of Sango, destroys the credibility of his mythic history.

20. This particular use for pidgin is supported by the terribly dated definition in Le Nortveau Petit Robert (Paris: Dictionnaires Le Robert, 1993), which identifies it as based on English--and presumably never on French. By contrast, Hachette's definition adds the following, "Systeme linguistique composite (quelles que soient les langues concernées) servant à la communication entre gens de parlers différents (plus complet que le sabir)" (Le Dictionnaire de notre temps 1991. Paris: Hachette.)

21. In this quotation I have added the numbers. Compare the words of (3) with the following: "Pidginization should be seen as any consistent reduction of the functions of language both in its grammar and its use" (Samarin 1971:126).

22. The statement is as follows: "Selon Samarin, le sango véhiculaire serait un créole ngbandi tout comme le haïtien un créole français [...]" (1982:86; all italics in this note are added). What I actually said was this: "Sango is a creolized language because it stands in somewhat the same relationship to vernacular Sango as Haitian Creole to French and Sierra Leone Krio [...] to English" (Samarin 1967:17, italics added). Elsewhere: "It merits being characterized as a creole language by the fact that it is a very much simplified form of a vernacular language of the same name [...]. It is therefore of a different genre than creole languages such as Sierra Leone Krio [...] and Haitian Creole [...], in that it is genetically fully African" (Samarin 1966:189, italics added). In any case, it is incorrect to declare that I am proposing a "modele créole" for Sango. For further discussion see below. 
Baratier's was not the first attestation to the existence of some kind of vehicular language along the Ubangi river. Nor was he a privileged witness of events at the end of the nineteenth century in central Africa. Rather than attribute the creation of the lingua franca to the Dendi, he attributed it to the local people. There is no evidence that the Ngbugu and Nzakara needed the Dendi as intermediaries, nor is there evidence that the Dendi played such a role. There was no ethnic group identifiable as Dendi at the end of the nineteenth century. Diki-Kidiri ignores the role that expatriate Africans played or could have played in the origin and spread of Sango. Contemporaries in the late nineteenth century attribute the origin of Sango to the local people. It would have been impossible for any ethnic group on the Mbomu river to have navigated and traded on the Ubangi river. There is nothing surprising or astounding about the spread of the new language in central Africa. Dendi was neither a commercial nor a vehicular language before 1887 nor was it different from Ngbandi. Although the chronology and events of the colonization of the Ubangi basin and the Haut-Oubangui are fairly well known, statements about the alleged expansion and changes in the vehicular language are vague. Sango is indeed both a pidgin and a creole.

1. Baratier's was not the first attestation to the existence of some kind of vehicular language along the Ubangi river. There are others. The first may be that of Victor Liotard, a French agent in the Mission Marchand in 1892, who noted in his papers the existence of the "langue commerciale" of the Yakoma. But the manuscript from which this is taken may have been written several years later, at which time the 'trade language' was well established 23 .

The next attestation chronologically may be the following from someone who was involved in the explorations between 1891-1894. Writing about what he calls the Ndri "idiome", he says:

1894 Les riverains de l'Oubangui, 'Sangos', Banziris, Bondjios et Bouzerous, ne s'en servent pas habituellement, mais le parlent presque tous (Brunache 1894:206).

Although there may have been some jargonization of the local Banda dialect by the interlopers, it is more likely, as I have sought to demonstrate elsewhere (Samarin 1985) ${ }^{24}$, that the Ndri were learning the Ngbandi-based pidgin (but still only a jargon in a technical sense in its earliest stage) that was to become Sango 25 .

23. Victor Liotard papers, ANSOM (Archives nationales section outre-mer, Paris) 213Mi2, first part, p. 108. On Liotard see Mazières 1982.

24. Further evidence is found in Maistre's assertion that the Ndri language had "de nombreux points de ressemblance avec les langues de la côte orientale, kiswahili et kiganda" (Maistre 1895:298). What he was noting, we now understand, was the presence of Bantu words in the emerging Ngbandi-based pidgin!

25. I use the terms jargon and pidgin as they have been commonly understood among linguists when discussing language contact and language change: a jargon is an unsystematic form of speech that characterizes either a given speaker or a group of speakers, or both; a pidgin is a stabilized form 
The next is that of Father Raoul Goblet, writing at the Mission Sainte Famille at Bessou on 31 July $1896^{26}$. He says that the missionaries (presumably at his mission, not necessarily at Saint Paul des Rapides at Bangui) are learning Langwasi (a variety of Banda, also spelled Langbasi), believing it to be the most widespread (presumably of the local languages) ${ }^{27}$, adding:

1896 Je ne parle pas de ce langage barbare de la rivière, qui fait que tu te comprends avec toutes les tribus riveraines. Ce n'est pas une langue, mais un volapuck quelconque 28 .

At the same mission on 7 September 1898 a certain Alexis Rousset, probably a member of an expedition passing through the area, recorded the following in his "Carnet de Route":

189880 à 100 enfants dont le plus âgé peut avoir 16 ans, le plus jeune 5 ans, tous rachetés: Banziris, Sangos, Togbos, Langouassis, N'gapous, M'Baggas, Monos, etc. ... vivant tous ensemble et se comprenant grâce à une sorte de sabir ou langage de rivière qui tient surtout du langage banziri 29 .

of speech, the consequence of pidginization in a language-contact situation. A pidgin can therefore be the object or goal of one's attempt at learning to communicate; a jargon by contrast does not provide such a grammatical model (used originally in Samarin 1986:23). 28 .

26. He was at the mission from 1895 to 1897 , his career ending when he died in Bangui at age

27. This is a curious observation, given the fact that the mission was actually in Gbanziri territory, as I gather from reading Banville 1986. There was nearby, however, a Langwasi village when the mission was founded; and other Banda-speaking groups-such as the Sabanga and Togbo-began to settle near the mission in order, we would assume, to share in some of the commercial advantages (Banville 1986). The use of Banda, nonetheless, seems to be confirmed by the TogboFrench dictionary published by Father Pierre Cotel $(b .1871-d .1914)$ in 1907 . He arrived at this mission in 1898, where he remained until 1903. His observations about the distribution of Banda dialects in the territory are surprisingly accurate for the time. It may have been the belief in the usefulness of Banda in its different forms that convinced the missionaries that they were better off learning Banda than the Ngbandi-based jargon. Fr. Cotel wrote the following about the former: "... avantage incomparable qui permet à tout Européen possédant convenablement l'un d'entre eux [i.e., Banda dialects] de se faire comprendre, à l'intérieur des terres, des rives de la Lobay jusqu'au Sultanat de Bangassou, aux Etats de Senoussi et aux portes de Fort Archambault" (1907:v).

28. Archives, Congrégation du Saint-Esprit, Paris (now Chevilly-Larue), V.181.B., Cahier 4.

29. ASOM (Académie des Sciences d'Outre-Mer, Archives), Paris, Fonds Bruel, B.173.16, cited in de Banville 1986:194). Since by the year 1898 the early form of Lingala would have been well established, I believe that Rousset's use of the phrase langage de rivière refers to a kind of language, something defined by its function or role. In any case, we have the following evidence that others than the children used the jargon. Fr. Goblet, the very one who declared he wouldn't use it, notes in a letter of November 1896 that on arriving at a Sabanga village on a trip in search of food and child slaves to redeem, he is warned by Bessou, the Gbanziri chief: "Prends garde à tes affaires [...], car ici ils sont 'dzi, voleurs" (Banville 1986:131-132). The word is Ngbandi-and now Sango-nzi 'to steal' (i.e., not 'voleur'). He also records: "The Baga tribe had learned that mokonzi Zapa [mokunzi Nzapa 'chief (of) God'] wasn't giving away merchandise for nothing" (page 133). Although Nzapa is a Ngbandi word, mokonzi--still in use in Sango-is a Bantu one. The occurrence of these Sango words lends incredulity to Rousset's unqualified assertion. An earlier piece of evidence that Ngbandi words were being used by the foreigners is the word attributed to the Ndri (Banda) for 'water': written as goungou, which is simply a repetition of $n g u$ (Maistre 1895:298). Elsewhere Maistre cites $\mathrm{Ba}$ Mingui as the name of the river in the area where the Aretou and Bazou people (apparently of 
We cannot be certain that it was indeed based on Gbanziri. It is more likely - given the facts cited below - that at this site the emerging pidgin was lexified to some extent by the local language. Since some pidgins if not all of them emerge when people over a period of time use whatever seems to work to accomplish their communicative needs, it is the most natural thing in the world that at one point along the Ubangi river the emerging pidgin would have some Banda words, at another place Gbanziri ones, and so forth. Besides, the grammar and dictionary of Father Pierre Calloc'h (1911), who was at this same mission from 1898 to 1903, reveals no significant amount of Gbanziri influence, as far as I can tell. And using Diki-Kidiri's manner of argumentation (see above), we would declare that if Sango were heavily influenced by Gbanziri, Father Calloc'h would have said so.

We have, moreover, the testimony of Georges Bruel. Arriving in the Ubangi basin in 1896, he would not have been among the first witnesses but would certainly have spent many hours with predecessors, possibly even some of the Belgian ones, In writing about French Equatorial Africa, this is what he says concerning "Langues commerciales et sabirs":

A côté de ces langues propres à chaque peuplade, les besoins commerciaux ou politiques ont amené la formation de langues 'passe-partout', qui ont emprunté à des langues faciles à apprendre des vocables dont les racines sont communes à plusieurs tribus et dont les règles grammaticales sont simples. Peu à peu, ces sabirs [possibly understood as pidgins] se sont répandus un peu partout à la suite des soldats, des conquérants ou ont été propagés par nos Sénégalais, par nos gardes indigènes, par nos employés de commerce noirs, par nos traitants, par nos travailleurs ou par des commerçants indigènes (Bruel 1935:164-165).

After commenting on several vehicular languages, Bruel discusses Sango: "En amont de Bangui, jusqu'à la frontière anglo-égyptienne et jusqu'au $8^{\circ}$ de latitude Nord, le Sango a fourni les éléments du sabir qui s'est diffusé un peu partout à la suite de notre occupation, parce que nous avons recruté, chez ces peuplades, nos premiers miliciens, nos premiers pagayeurs (les Banziri et les Bouraka, en relation fréquente avec les Sango, savaient déjà leur langue) et les auxiliaires de nos commerçants" (1935:165-166; practically the same wording

Banda ethnicity) live (Maistre 1893:7). This phrase is equivalent to Sango's bà mingi '(the river) twists (or winds) a great deal.' Maistre's voyage to the Haut-Oubangui was from February 1892 (embarking at Bordeaux on 10 January) to April 1893, for which see Maistre 1893. See also his report in the national archives (ANX 2D10). In the latter we learn that Greshoff, the representative of the Dutch trading company, lent him fifty Vhyboys (that is, Vai, from West Africa, probably what became Liberia). Because of their employment up the Ubangi river, the latter would most certainly have acquired some knowledge of Ngbandi, and it was from workers of that area who seem to have contributed to Sango the word that has come to mean 'money' [Samarin 1989b]. Moreover, Maistre's 'Carnet de route' (ASOM), number 2 for " 24 avril-12 juin 1892 (de Brazzaville à la Kémo") lists on the first page ninety persons who appear to be his personnel: 50 Vhyboy, 10 [Kassai?], and 10 [Kroumen?]. On West Africans in the colonization of the Ubangi basin, see Samarin 1989a.) 
in Bruel 1918:170). However, Bruel's brief history of Sango cannot be accepted for the following reasons. (a) It is not clear that what he says applies to the time when the whites first arrived. (b) Even if (some, we should say, of) the Gbanziris and Burakas - whose language varies only in a dialectal way, if at all- spoke vernacular Sango, this fact is not evidence that the latter was a lingua franca. After all, they were neighbors and were engaged in the same kinds of activities -trading and fishing. Given this situation, we would expect that some of the Sangos would also speak Gbanziri-Buraka. It is only when language learning is one-sided that we have possible evidence for the emergence of a lingua franca (Samarin 1987). What is needed, obviously, is a statement that other Ubangians, further removed from the Sangos, were speaking their language.

2. Baratier is not a privileged witness of events at the end of the nineteenth century in central Africa. What he writes has to be examined and judged critically and compared with other evidence - a procedure that is fundamental to all historical research. It is therefore misleading if not preposterous to assert that Baratier was one of the first Europeans in the area (DK 1981:34). He may have been one of the 'first' when compared with the number who came in the following fifty years, but not when compared with those who came in the preceding ten years.

The following is only a small portion of a large corpus of evidence for the opportunity and even need for a jargon to develop in the 1880s and $1890 \mathrm{~s}{ }^{30}$.

The very first Europeans incontestably were Captain Alphonse Van Gele (in Flemish; Vangele in French; b. 1848, d. 1939) and his party in the service of the Congo Free State ${ }^{31}$. Having failed in October of 1886 to go beyond the rapids of Bangui, he came back in 1887, starting from the equator - where he gathered provisions and canoers - in one steamboat and a large canoe. He continued his exploration as far as the headwaters of the Ubangi river into the following year, arriving back at Leopoldville in February 1888 - a period of about five months in ail. He returned in 1889 , leaving Leopoldville on 21 May, this time with three steamers, one allege, and one large canoe, accompanied by six other whites (one of whom dies in May 1891) and one who is identified as Maltese, going up the Ubangi in June. The non-white members of the expedition consisted of ninety men (of whom three, however, drowned in July): Zanzibari, Hausa, so-called Bangala, and a servant from Sierra Leone. This was Van Gele's longest period of stay, not leaving the post of Yakoma to return to Leopoldville until September of 1891. By this time he had established treaties with most of the people in the Ubangi basin, apparently as early as 1887 . (Treaties were made on both banks of

30. My argument seems to be similar to the one called the "hypothèse KERUX" (DK 1981:31).

31. At this time Van Gele had the rank of Inspecteur d'Etat, Commissaire de district. Therefore the significance of the following statement has been ignored: "Van Gèle est le premier explorateur qui ait reconnu la région habitée par les Yakomas [...]" (Girard 1901:55). 
the river and a post established on the right - soon to become French - bank.) Along with major treaties up the Mbomu river with sultan Bangassou, Van Gele made treaties with Ngbandi chiefs in the Ubangi basin fed by the Mbomu and Mbili rivers who were not subject to Bangassou, and he established the post of Yakoma among them on 30 May $1890^{32}$. In this same year Van Gele, after sending emissaries to Ganda and Bangassou, received Bangassou and his brother Lengo at Yakoma, being presented with the gift of a ton of ivory. Bangassou also signed a treaty with Van Gele, placing his territory under the protectorate of the EIC (Lotar 1937:77; Cuypers 1960). From the earliest occasion until 1894, when King Leopold II agreed with the French to withdraw from the territory that had been occupied north of the Ubangi river in return for certain concessions, the Mbomu river basin must have become familiar territory for the Europeans serving the Congo Free State as well as for their expatriate auxiliaries.

In any case, it must have been during these earliest months and years of exploration, treaty-making, and occupation of territory that the linguistic diversity among all the participants in the frequent and various encounters lead to the jargonization of the language of the most populous and most serviceable people - the Ngbandi. We can provide detailed information about the European and expatriate African personnel, but mostly for the French. For the sake of brevity, it will simply be noted that in November 1890 Van Gele went to Bangassou to get reinforcements for his expedition to Djabir, and received twenty men (Janssens \& Cateaux 1908:178). In January 1892 Bangassou gave the Belgians some Kpatiri whom he had just conquered: they were to become soldiers in the Force Publique, trained at Yakoma (Dampierre 1967:103; for their ethnolinguistic relationship, see below). And on 22 September 1893 S. de Brazza wrote a letter to Chavannes, informing him that the Belgian force near the Mbomu could be estimated at a thousand men (Chavannes 1937:331). This is not an unreasonable number when we remember that by late 1891 at the station of Yakoma alone 150 liberated slaves had received military training, suggesting that at all or some of the other Ubangian posts other local inhabitants were being recruited in one way or another into the Force ${ }^{33}$. Indeed, in that year or the year before there were at the EIC post at Bangassou another 150 men and five Europeans (Mazières 1982:51). The mixture of Ngbandi-speaking persons among the linguistically diverse population under the authority or the 'protection' of the Belgians would have been an ideal culture (biologically understood in a metaphorical sense) in which a pidgin could emerge. Add to these the personnel of the trading companies, the first of whose factories were under the supervision of Alexandre

32. This is based on my study in 1980 of the Van Gele archives in the library of the museum in Tervuren, Belgium. See also Cuypers 1960; Samarin 1989a.

33. Unless otherwise noted, information relating to Van Gele comes from Cuypers 1960. 
Delcommune, who arrived on the scene on 10 September 1891 , followed by the Dutch trading company ${ }^{34}$. Add also to this fact that Van Gele himself and some of his colleagues remained in the area for twenty-eight months - as was established above- and one has all the factors necessary for the emergence of a pidgin. And during much of this time everyone in the expedition must have had to live off the land -in killing game and buying provisions from the local people, because on 16 July 1889 all the "conserves de l'expédition" were lost in dangerous water.

3. There is no evidence that the Ngbugu and Nzakara needed the Dendi as intermediaries, nor is there evidence that the Dendi played such a role ${ }^{35}$. Apart from the fact that no substantiation is provided for the assertion noted above, we would have to be very skeptical of any alleged evidence. After all, thousands of other ethnolinguistic groups in Africa were able to negotiate with each other in peace and in war in the usual way: using people who had become bilingual as the result, for example, of marriage or slavery. Moreover, in one place at least there was an enclave of eight Nzakara villages right in the middle of Ngbugu territory just north of Mobaye ${ }^{36}$. In any case, it would appear that the Dendi were in no position to play the role of mediator. They were neither in the commercial circle of the Yakoma at the mouth of the Mbomu nor in that of the asssimilated Ngbandi who had conquered this area and had adopted the local language (Dampierre 1967). Indeed, their position seems to have been one of inferiority. Some, if not all, of them were subject to sultan Bangassou, a Nzakara-speaking chief of Ngbandi ancestry (Julien 1899; Julien 1902:113; Bonnel 1901:16; Colrat 1902:91; Dampierre 1967:201, fn 25) ${ }^{37}$. Moreover, a contemporary of Baratier, but a resident officer, said the following of the Yakoma, not the Dendi: "Les Yakomas passent aux yeux des autres noirs comme ayant le monopole du bon ton, de l'élégance: aussi voit-on depuis quelque temps les Bougbous des deux sexes singer les Yakomas dans leurs faits et gestes" (Julien 1898:113) ${ }^{38}$. And since Bangassou -armed with between 1,000 and 2,500 (and even more)

34. About 1890 there was, for example, a factory, of the Dumas company at Setema and at Ouango one of the Dutch trading company, Nieuwe Afrikaansche Handels Venootschaap (NAHV) (Mazières 1982:40).

35. Indeed, it was said that it was the Yakoma-therefore not the so-called Dendi-who were "les intermédiäres forcés entre les Européens et les naturels de l'hinterland" (Julien 1901:114).

36. Map, Bobichon, ANSOM AF 670; Bobichon, AF 707; Julien, AF 718. By moving close to the Ngbandi in this region (later to be called Sango), the Nzakara were able to go directly to the source of items they wanted in trade: e.g., ivory.

37. Julien 1901:113; 'Rapport de Bangassou,' January 1903, ANX 4(3)D9.

38. This statement cited in Dampierre 1968 is ignored, or else its significance is not seen. The Yakoma, in my opinion, were copied "depuis quelque temps" by others, precisely because they had acquired all kinds of objects and a life-style based on their intimate contact with Europeans. This hypothesis is confirmed by the allegation that the Sango and Yakoma had acquired complete monopoly of trade in this area following the defeat of the Bubus [sic] by Senegalese troops (Mazières 1982:39). But this latter author does not consider the possibility that this commercial hegemony had begun under the Belgians. 
men, some of them with rifles - engaged in regular forays among the neighboring Bandas (such as the Ngbugu), even up to the year 1902, one cannot suppose that he needed the help of some underlings as translators. Among his slaves he certainly had all the languages he needed. A commandant reports -after naming five Nzakara villages on the left bank of the Kotto river, which had "fortes garnisons bien armées" - that their purpose was to provide Bangassou with slaves. At one village there were 2,000 houses, with about 8,000 inhabitants "presque tous esclaves M'Boubous et langbas" 39.

It is reasonable, therefore, to assume that at first all (or several) of the varieties of Ngbandi were being jargonized, and if there was a preponderant number of Kpatiri, their learning of the jargon might have been easier than learning Ngbandi, somewhat related to their own language.

4. There was no ethnic group identifiable as Dendi at the end of the nineteenth century. In 1890 Van Gele reported that the Nzakara called the "Denndy" those natives who had a line of pois (apparently cicatrices) starting from the middle of the head to the nose ${ }^{40}$. In 1896 it was reported that the name Dendi applied to "gens de l'eau", in opposition to the "gens de terre" (Donnay 1896:366). In this Yakoma zone administered by the French the latter were Nzakara, Zande, and Bongo (using contemporary spelling), whereas the former were Gamba, Bado, Bira, and Gembele (where the author includes the ethnic plural prefix and the French suffix: e.g., Agambas), who are found along the banks of the Ubangi, the Uelle, the Mbomu, and the Mbili rivers (Donnay 1896:366; see also Julien 1901:111,113 and Boyeldieu 1982). However, one map locates a 'tribe' of Dendi south of Bangassou and at some distance west of the Mbomu river (Colrat de Montrozier 1902; similarly located in Bruel 1935). Another one describes the Dendi as being a mixture of Yakoma and Bugbu (Julien 1899); another as "une race mâtinée" of Yakoma and Nzakara (Colrat 1902:90). A map in the Bulletin de la Société de Géographie locates Dendi below Ouango, and almost to the mouth of the river ${ }^{41}$.

Contrary to the impression that we are led to have of the Dendi, they appear to have been a lusterless people in the 1950s, not long after Sango had become - as I am striving to establish - a stabilized pidgin. In 1953 the total population of the district of Ouango, in which Dendi were to be found, was 35,000 (Martin 1952:130), of whom in 1954 the Dendi numbered only 3,738 (Éric de Dampierre, handwritten personal communication, some time in the 1970s;

39. Lieutenant Bos, Commandant le Cercle N'Sakara, to commissaire général dans le HautOubangui, Bangassou, 2 January 1901. "Rapport de tournée."

40. Van Gele Ab, II, 5 June 1890. But this kind of cicatrice did not distinguish the so-called Dendi from other Ngbandi-speaking people. According to Girard (1901:81) this facial decoration (in my words) characterized the Yakoma and Sango-making no reference whatsoever to Dendi.

41. 1901, premier semestre, planche 1. Ministère des Colonies, Service de géographie, collection Afrique équatoriale française, Section AF887, carton 88, no. 407. 
compare with the estimate of 50,00 above), and in 1959 they are located in one map in just two places: inland, immediately north of Ouango, and further inland on the road from Ouango to Gomba ${ }^{42}$. Moreover, not only was the "paysannat" of this area "très hétérogènes" (including, for example, Langba and Nzakara) but it included many who were also "descendants des anciens esclaves de case" (Martin 1952:78, 79, 167).

An interview by a Central African revealed the following from a so-called Dendi (Zigba 1995:49, 50, 51): "Nous n'avons aucun ancêtre du nom de Dendi." The latter gave the following explanation about the origin of the name Dendi: "Les Blancs étaient arrivés chez lui [Bangaso (sic)]. Ils parlaient une langue que lui, n'avait jamais entendu de sa vie." The whites came to him for "houes" [iron money] (see Samarin 1989b). Bangassou's people, the Nzakara, did not make them, so he had to send to Malendere for the hoes. Each time the whites came he told them, speaking through an interpreter, mo poi colonel yami tomesongo ka dendi zo (toi dire que moi envoyer dire aval là-bas) ${ }^{43}$. When Bangassou spoke of Dendi, he was thinking of the village Ngalo; that is where the hoes were made. In short, "Dendi désignait tout simplement toute la région en aval [où l'on fabriquait les houes]."

The above fruit of field work is supported by the statement that the Dendi (or at least the agricultural ones in the Ouango district) referred to themselves by the clan name Zien N'Gaké, except when they distinguish themselves from other ethnic groups, at which time they call themselves - as might be expectedAbandiya; the name Dendi, they avow, was given to them by the Nzakara with the meaning "les gens qui habitent en aval" (Martin 1952:78, 79). At an early date, as we have seen, all Ngbandi were referred to -or were understood by some Europeans- as Dendi. The name Dendi in any case was just a guess on someone's part, because names were being attributed to these people in a haphazard manner. Much could be said about the arbitrary and inconsistent manner in which Europeans gave names to local populations and their languages (see Boyeldieu 1988 and Samarin 1984/1985 with respect to the Ngbandi and Sango respectively and for the Bondjo Samarin 1984b; Baker 1996:96 on language names).

5. It would have been impossible for any ethnic group on the Mbomu river to have navigated and traded on the Ubangi river. Transportation and trade on the Ubangi river, as on the Congo river, was determined by a string of monopolies (we might call them), each group trading with the immediately

42. RCA enquête 1959 .

43. The language here is not identified by Zigba, but according to Éric de Dampierre (personal communication, 14 November 1996) it is Nzakara, but written "in a silly way." He provides the following translation: "[Le roi]: 'Dis au colonel que j'ai envoyé les instructions [nécessaires], là-bas en aval [i.e., à Ngalo], pour que ce travail soit exécuté." Dampierre also adds that at that time there would have been no grade of colonel. 
neighboring one. For example, the Gbanziri were in competition with the Ngbandi upriver and were prevented from going downriver by the Ngbaka around Bangui. Only when the Gbanziri became allies of the whites were they able to establish themselves at Ouadda (Wada), for example 44 . This matter is more fully discussed and documented in Samarin 1984 and 1984/1985.

Although the ownership and use of canoes is relevant to the history of colonization in the area, it must be understood that the Ngbandi people were not the only ones who were river people. An inventory of canoes on the lower Kotto river, for example, revealed that there were 374 canoes, distributed in the following way, grouped here by linguistic relationship - Ngbandi, Banda, Nzakara (Julien 1898:104; see also Samarin 1984/1985:345 for more details; for ethnic names, Moñino 1988):

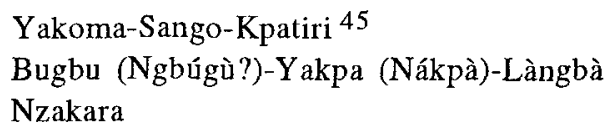

51.9 percent

45.7 percent

2.4 percent

6. There is nothing surprising or astounding about the spread of the new language in central Africa. The geographical expansion of Sango was the most natural thing in the world, given the circumstances. All of a sudden -and from the very beginning of colonization - there was contact between people who needed - or for whom it was advantageous to have - a contact language, a lingua franca. What led to the emergence of this new language was also what led to its spread. There was nothing mystical or magic about its expansion, no more so than the spread of Tok Pisin in Papua New Guinea, and of Fulani, Hausa, Pidgin English, and Swahili in Africa. The fact that people were acquiring the language here and there and at first in small numbers throughout the territory of Haut-Oubangui only reveals that representatives of the French government - and primarily members of its militia - and possibly Muslim traders were able to move about because of the pax franca. In this very area, for example, at the end of 19004,000 porters and canoers were used in the Cercle N'Sakara by the government's posts and by the exploitive societies ${ }^{46}$.

Moreover, it cannot be denied that Baptist missionaries, whose policy it was to use only Sango, must have contributed to the spread of the pidgin in the territory in which they worked - from Bangassou in the east to Ft. Crampel in the west, i.e., throughout Ngbandi, Banda, and Ngbaka-Gbaya territory. Their

44. Victor Liotard archives, 'Journal', 4 February 1892, ANSOM-Mi 213.

45. The Kpatiri-or Gbayi, as they call themselves-are either closely related to the Ngbandi group or else constitute another subgroup of the Ubangi family (Moñino 1988).

46. Lieutenant-commandant le cercle N'Sakara. To délégué du commissaire général dans le Haut-Oubangui. Bangassou, 3 January 1902 (ANX4[3]D8). 
role is significant, given the fact that they arrived in the early $1920 \mathrm{~s}$ - that is, not very long after the pidgin had become stabilized, as I want to argue 47 .

The so-called Yakoma, it can easily be demonstrated, were among the first indigenous French recruits as they had been for the EIC. For example, there is mention of twenty "auxiliaires yakomas" having arrived at Mbari-Rengo (whose location has not been determined) from Bangassou in 190148 .

7. Dendi was neither a commercial nor a vehicular language before 1887 nor was it different from Ngbandi. Although I do not have direct evidence to support this claim, no one has evidence to contradict it -in other words, to verify the opposite view. The following assertion is not the evidence that is needed: "Ce contact permanent avec les Ngbougou et les Nzakara entraîna l'altération de la langue ngbandi qu'utilisent les Dendi, et donna naissance à un parler véhiculaire nommé 'dendi'(DK 1986:85). It has never been demonstrated that prolonged contact by speakers of different languages necessarily leads to the emergence of a lingua franca. The most obvious consequence of language contact is bilingualism. But it is claimed that those who retained their original language, Ngbandi, considered their "aînés de seigneurs déchus ... Ce mépris subsiste encore aujourd'hui, et plus particulièrement envers les Dendi sur la base des mêmes griefs: altération de la langue et métissage poussé avec les ethnies voisines, notamment, les Nzakara et les Ngbougou" (DK 1986:85; but see Dampierre 1967:181, where Girard 1901:84 is cited, but neither of which is cited along with the passage just quoted) ${ }^{49}$. The reason, however, would appear to be that the Dendi simply had contact with both the Ngbugu and the Nzakara, not that the latter were in permanent contact with each other. A lingua franca by definition is a language that is used by and among people for whom it is not a native language. For Dendi to have been such a language, it would have had to be used by, for example, the Ngbugu and the Nzakara - without the mediation of the Dendi.

Although Diki-Kidiri claims that the Dendi language was altered and mixed because of contact with other languages of the area, the French specialist on Ngbandi asserts the contrary (Boyeldieu \& Diki-Kidiri 1982).

8. There is no linguistic evidence of Dendi's having had the alleged importance in the origin, development, and spread of Sango. If the Dendi language were as different as it is alleged to have been in the nineteenth century, some traces of its peculiarities would likely have remained early in this century

47. Their mission is called Baptist Mid-Missions and is an arm of the General Association of Regular Baptists, with headquarters in Cleveland, Ohio.

48. Mission Bos, 1901, ANX 2D-25.

49. In any case, all that Dampierre says is that the Nzakara "méprisent" the Ngbandi who had settled among them, for example, at Ouango and Kembe. It is important to note, moreover, that if the so-called Dendi were among these, "[ils] ne perdent jamais contact avec leur village d'origine", downriver to the Ubangi, obviously (Dampierre 1967:181). 
and possibly even until the present day. No such evidence has yet appeared. Several of Dendi's distinctive features are noted in Boyeldieu 1982.

9. Contemporaries in the late nineteenth century attribute the origin of Sango to the local people. Baratier attributes (and in the context accepted as true) "la formation [de dendi] aux seules relations permanentes entre les populations riveraines" (DK 1981:35). But Baratier in the statement quoted above is referring to the people along the Ubangi, all of whom from Ouango to Mobaye were Ngbandi.

10. Although the chronology and events of the colonization of the Ubangi basin and the Haut-Oubangui are fairly well known, Diki-Kidiri's statements about the alleged expansion and changes in the vehicular language are not convincing. He does not, for example, use Dendi as the name of the language, only 'Dendi.' (See footnote 12.) Although Père Calloc'h's grammar and dictionary of Sango was not published until 1911 (that is, after Bangui had become the capital of the territory), we can reasonably assume that he was using this name for the lingua franca before that date.

It is surely wrong to interpret Baratier's statement - "ces primitifs ont realisé ce que nous autres civilisés n'avons pu encore faire"- to mean that the Ubangians and not the Europeans made the Ubangian trade language. The statement means nothing more than 'In Europe we haven't succeeded in creating a vital international language.' Furthermore, Diki-Kidiri never refers to what Baratier says about the pidginized nature of the Ubangian 'volapuk.' While acknowledging that some "alterations" took place during the history of what has come to be Sango, he does not admit the magnitude of the changes: the vocabulary drastically reduced, the grammar - as technically defined - almost entirely vanished, leaving syntax to carry most of the burden. In the following statement we are informed that Sango has been transformed, but not in the lexical impoverishment of the Ngbandi language, but by an enrichment. And grammatical reduction is made to appear as if it were simply the replacement of one system by another.

Le sango, ... issu du dendi dont il portait le nom à la fin du siècle dernier, a subi de nombreuses transformations structurelles. Le lexique s'est considérablement enrichi par des emprunts surtout au lingala, au banda, et au français, mais aussi par de nombreuses créations nouvelles spontanées. La syntaxe est devenue plus analytique en privilégiant l'usage d'auxiliaires verbaux pour assumer les valeurs aspecto-modales [DK 1988], plutôt que le compact système des schèmes tonals caractéristique des parlers yakoma [Boyeldieu 1975] (DK 1982:81; references in brackets are added here). 
11. Sango is of course a pidgin and a creole ${ }^{50}$. The reason for calling Sango a creole is that for many people this pidgin is the first language learned in childhood: many of them do not know an ethnic African - Central African or other- although some of them later in life acquire other languages through interaction with friends, elderly relatives, etc.

\section{CONCLUSION}

It has been demonstrated, one should hope, that the attempt to account for the history of the Sango language without taking into account its origin as a pidgin in the context of colonization leads one onto quicksand from which there is no further journey into truth. Historical data of many kinds lead to the conclusion that the ancestor of the present language came into being simply because foreigners (very few of whom were white) and autochtonous peoples speaking many different languages had to communicate intensely in a relatively restricted area. Although there were not too many different languages along the banks of the Ubangi river, the dramatis personae of the late nineteenth century found it convenient to make do with various forms of the Ngbandi language, because they were the first to be in greatest contact with the foreigners and because their way of living made it possible for the incipient pidgin to be seeded on both banks all along the middle and upper Ubangi. This is the best explanation that historical and linguistic research can arrive at, supported, of course, by what is already known about pidgins. There is no mystery to Sango's origin. Indeed, given the circumstances, the origin of this pidgin is even banal (on a similar view with respect to French creoles see Baker 1996:108, 117).

50. The earliest of my claims to this effect are the following: "There is an increasing number of people for whom [Sango] is a first language, and for these it would be considered a creolized language, using the term in one of its senses" (Samarin 1966:137)"; "[...] lingua franca Sango is like Pidgin English, Haitian Creole, and Portuguese Crioulo in being a 'simplified' form of a natural language" (1967:ii); [Because the vernacular language came to be used as a lingua franca] "[...] it was very much simplified and to some extent transformed in structure"; "Because it is a creolized (by some people's definition even a pidginized) language, [...]." (1967:17). See also Samarin 1971:126; Samarin 1984a; Taber 1964:1; Taber 1965:xiv. The unknown person who translated the original version (of 1984a) into French (and which I never was given the opportunity to edit before its publication) rendered my "Pidgin Sango" as "sango sabiresque" (Samarin 1984/1985:310; cf. 1984:180, "become the dominant contact language of the Ubangi basin" as "le sango vernaculaire commença à être sabirisé" (Samarin 1984:192; cf. 1984/1985:326), "Bantu pidgins" as "des sabirs bantus" (1984/1985:34; cf. 1984:204), "Pidgin Sango" as "sango sabirisé (1984/1985:359; cf. 1984:217 -and for the following two as well), "a pidginized form of it [i.e., the vernacular] as "forme sabirisée de celui-ci", and "the emerging pidgin" as "le sabir naissant." I would have preferred a more rigorous use of technical terms. 
There is nothing mysterious about the history of Sango. Although there are things that are uncertain and others unknown and even unknowable, we approach the task of understanding what Sango is and how it came to be what it is as we do anything in the history of humankind, collecting every possible piece of evidence, examining and evaluating all of it dispassionately and objectively. The product of this labor must be explicit and logical. The final judgment will be convincing and satisfying. A myth - or a mythic history - comes into being in a different way: it is unlike an intellectual accomplishment.

Myths, of course, have their functions, and they are not limited to preliterate societies. In modern political states - as for imperial Rome - myths contribute to social solidarity and are powerful motivators in times of crisis. It is therefore understandable that some would like the Central African Republic to have its own endogenous language: something that is not in any way a consequence of the contact of diverse languages when Europeans occupied Africa. It is not surprising, therefore, that we should find other attempts to indigenize language history in Africa. For example:

Quant aux quatre véhiculaires de la colonie [i.e., belge: Monokutuba, Lingala, Swahili, ChiLuba], leur reconnaissance comme langues principales remonte à bien avant 1900. On sait en effet que des contacts fréquents, des courants intenses d'échange existaient depuis longtemps entre diverses populations parlant des langues et des dialectes différents quoiqu'apparantés. Toutes les thèses tendant à faire de ces langues de purs produits de la colonisation sont à l'évidence erronnées (Ngalasso 1986:17; see also Ngalasso 1982).

Apart from the fact that this assertion is not supported by scholarly research for any one language - let alone for all four- this writer is naive in his citing as sufficient causes for the emergence of lingua francas (1) frequent contact and (2) linguistic diversity. The consequences of language contact as well as the nonlinguistic factors that are implicated in their outcome are numerous and not always easy to identify. And when languages change drastically as a result of different kinds of contact between human beings, no simplistic explanation should be tolerated.

In any case, new languages could have emerged in Africa at any time in the whole era of colonialism without the colonists being involved at all. Whites did not create Monokutuba, Lingala, and Sango -Africans did. (See Samarin 1986, 1990 for the first two languages.) ${ }^{51}$ Men (and some women) who came from other parts of Africa to work for whites in all kinds of ways - not merely as soldiers - interacted with the inhabitants of central Africa in all kinds of ways. Many deserted and remained with the local people; others chose to stay after

51. The linguist of Zairean origin, Salikoko Mufwene, also a specialist on creoles and pidgins, studies these Bantu languages as I do, and comes to conclusions different from Ngalasso's. See Mufwene 1987, 1989, 1990, 1991, 1992, 1993, 1997. 
their contracts were finished. Many took local women as wives and with them bore children. Not all relations were as sinister as the stereotyped image makes them to be.

Sango, therefore, is an African language not because it acquired a vehicular function before whites arrived, but because it simply came into existence when Africans speaking many different native languages needed to communicate with the Ngbandi-speaking people of the upper Ubangi river, followed by the need that central Africans had - sometimes by obligation, to be sure, but sometimes by choice - in communicating with each other. It was unusual that a pidgin came into being in this particular instance of language contact. This fact makes the history of the Central African Republic especially valuable to linguists. Whereas language contact is ubiquitous, the rise of pidgins as stable forms of language is much less common than bilingualism and language shift. Recognizing the pidgin ancestry of Sango does not denigrate it. In spite of its limitations by comparison with its co-territorial and historic languages, its value to the nation is indisputable (Samarin 1962). Moreover, the failure to admit what it really is as a language (that is, genetically and typologically) - namely, a pidgin- leads to erroneous socio-cultural as well as linguistic history.

William J. SAMARIN

\section{REFERENCES}

ALLÉGRET (Marc)

1987 Carnets du Congo: voyage avec Gide. Paris: Presses du C.N.R.S.

BARATIER (Général Albert E. A.)

n.d. Vers le Nil: souvenirs de la Mission Marchand de Brazzaville à Fort Desai. Paris: Arthème Fayard \& Cie.

BAKER (Philip)

1996 Pidginization, creolization, and français approximatif. Journal of Pidgin and Creole Languages 11(1):95-120, a review of Chaudenson 1992.

BOUQUIAUX (Luc, et al.)

1978 Dictionnaire sango-français, lexique français-sango. Langues et civilisations à tradition orale, 29. Paris: SELAF.

BOYELDIEU (Pascal)

1975 Études yakoma, langue du groupe oubanguien (RCA). Morphologie synthématique. Notes linguistiques. Bibliothèque de la SELAF, 47-48. Paris: SELAF.

1982 Structures sociales et particularismes linguistiques en pays de langue 'ngbandi': éléments pour une étude (rapport d'une mission CNRS en Centrafrique, mars-avril 1977). In Le domaine ngbandi by Pascal Boyeldieu \& Marcel Diki-Kidiri. Paris: SELAF, p. 13-80. 
BRUEL (Georges)

1935 La France équatoriale africaine: le pays, les habitants, la colonisation, les pouvoirs publics. Paris: Larose Éditeur.

CHAUDENSON (Robert)

1992 Des îles, des hommes, des langues. Paris: L'Harmattan, p. 310.

COLRAT DE MONTROZIER (Raymond)

1902 Deux ans chez les anthropophages et les sultans du centre africain. Paris: Librairie Plon.

COTEL (Le Rév. Père Pierre, C.S.E)

1907 Dictionnaire français-banda et banda-français précédé d'un essai de grammaire banda. Brazzaville: Mission catholique.

\section{CUYPERS (J.-P.)}

1960 Alphonse Vangele (1848-1939): d'après des documents inédits.

DIKI-KIDIRI (Marcel)

Bruxelles: Académie royale des sciences d'outre-mer.

1977 Développement du sango pour l'expression du monde moderne: obstacles et possibilités. In Les relations entre les langues négroafricaines et la langue française. Colloquium, Dakar, 22-26 March 1976. Paris: Conseil international de la langue française (CILF), p. 717-728.

1978 Grammaire sango: phonologie et syntaxe. Thèse de $3^{\mathrm{e}}$ cycle de l'ancien régime. Director: Maurice Houis. Paris: Sorbonne nouvelle, Université de Paris III. 200 pp.

1979a L'émergence du sango comme langue nationale centrafricaine Recherche, Pédagogie et Culture. Vol. 8, $\mathrm{N}^{\circ} 43$, Langue, individu, société, p. 36-39.

$1979 \mathrm{~b}$ Créations lexicales spontanées en sango à partir d'emprunts au français. In Contacts de langues et contacts de cultures 3, ed. by Jean-Pierre Caprille. (LACITO-Documents, Série Afrique, 6.) Paris: SELAF-ACCT, p. 33-43.

1981 L'expansion du sango en Centrafrique. In L'expansion des langues africaines: peul, sango, kikongo, ciluba, swahili, ed. by Jean-Pierre Caprille. LACITO-Documents, Afrique 8, série "Contacts de langues et contacts de cultures." Paris: SELAF, p. 29-42.

1982 Variations libres entre phonèmes en sango langue nationale de R.C.A. Etude et mesure. In Le domaine ngbandi, ed. by Pascal Boyeldieu \& Marcel Diki- Kidiri. Paris: SELAF, p. 81-103.

1985a Le sango entre l'oralité et l'écriture. In Passage à la lecture en Afrique. No place. AELIA (Association d'études linguistiques interculturelles africaines). Bulletin, $\mathrm{n}^{\circ}$ 8, décembre. Actes $\mathrm{du}$ colloque international sur le passage à la lecture en Afrique noire. A.E.L.I.A., A. P.E.L.A., O.R.S.T.O.M., \& Université de Bénin, p. 39-46.

1985b Elaboration de terminologie scientifique dans une langue de tradition orale: le sango, langue nationale centrafricaine. Discoss $1: 77-82$.

1985 c La création lexicale en sango. Manuscript. 29 p.

1986 Le sango dans la formation de la nation centrafricaine. Politique africaine, 23:83-99. Paris: Karthala. 
DIKI-KIDIRI (Marcel)

1987a. La situation du sango en République Centrafricaine. Etudes de Linguistique Appliquée. Politiques linguistiques (Études de cas), coordonné par Henri Boyer \& Pierre Dumont. Nouvelle série, $\mathrm{n}^{\circ} 65$, p. 102-109.

1987b Le complétif direct et indirect en sango. In La maison du chef et la tête du cabri: des degrés de la détermination nominale dans les langues d'Afrique centrale, ed. by Pascal Boyeldieu. Paris: LACITO, Département Langues et parole en Afrique centrale (LAPAC)/ Librairie orientaliste Paul Geuthner, p. 113-125.

1988 Aspects, modes et temps en sango. In Temps et aspects, ed. by Nicole Tersis \& Alain Kihm. Actes du colloque C.N.R.S., Paris, 24-25 octobre 1985. Numéro spécial, 19. Paris: Peeters \& SELAF,

FROMENT (E.) p. 117-124.

1889 Un voyage dans l'Oubangui, de Liranga à Modzaka. Bulletin de la Société de géographie de Lille, $10^{e}$ année, tome 11, p. 180-216.

GÉRARD (M.)

1930 Sango, langue commerciale de l'Oubangui. Rome: Éditions Sodalité de Saint-Pierre Claver.

GIRARD (Henry)

1901 Yakomas et Bougous, anthropophages du Haut-Oubangui. L'Anthropologie 12:51-92.

HARMS (Robert W.)

1981 River of wealth, river of sorrow: the central Zaire basin in the era of the slave and ivory trade, 1500-1891. New Haven: Yale University Press.

KÊRUX, E. \& SAN-YOUEN

1950 Sango. Berberati: Mission catholique de Berbérati.

MAISTRE (Casimir)

1893 (?) La mission Maistre. Rapport. Bulletin du Comité de l'Afrique française dans l'Afrique centrale, p. 2-11.

1895 A travers l'Afrique centrale du Congo au Niger 1892-1893. Paris: Librairie Hachette \& Cie, p. 301.

MAZIÈRES (Anne-Claude de)

1982 La marche au Nil de Victor Liotard: Histoire de l'implantation française dans le Haut-Oubangui 1891-1899. Aix-en-Provence: Université de Provence.

MUFWENE (Salikoko)

1986 Les langues créoles peuvent-elles être définies sans allusion à leur histoire? Études créoles 9.

1987 Formal evidence of pidginization/creolization in Kituba. Annual Conference on African Languages and Linguistics, Montréal, Québec.

1989 La créolisation en bantou: les cas du kituba, du lingala urbain, et du swahili du Shaba. Etudes créoles 12(1):74-106.

1990 Time reference in Kikongo-Kituba. In Pidgin and creole tensemood-aspect systems, ed. by John V. Singler. Creole Language Library, 6. Amsterdam \& Philadelphia: John Benjamins, p. 97-117. 
MUFWENE (Salikoko)

1991 Pidgins, creoles, typology, and markedness. In Development and structures of creole languages, ed. by Francis Byrne \& Thom Huebner. Creole Language Library, 9. Amsterdam \& Philadelphia: John Benjamins, p. 123-143.

1992 A propos de substrat et superstrata dans la genèse des créoles: les vrais et les faux problèmes. Etudes créoles 15(1):135-149.

1993 Créole, créolisation, substrat, et autres notions apparentées: quelques réflexions sur Des îles, des hommes, des langues: langues créolesculture créoles de Robert Chaudenson. Études créoles 16(2):117141.

1994 Restructuring, feature selection, and markedness: from Kimanyanga to Kituba. Berkeley Linguistic Society. Pp. 1-22.

1997 Kituba. In Contact languages : A wider perspective, ed. by Sarah G. Thomason. Amsterdam \& Philadelphia. (In press)

Ngalasso (Mwatha Musanji)

1982 Émergence et développement d'une langue véhiculaire: le kikongo. In L'expansion des langues africaines: peul, sango, kikongo, ciluba, swahili, ed. by Jean-Pierre Caprille. LACITO-Documents, Afrique 8, série "Contacts de langues et contacts de cultures." Paris: SELAF, p. 43-72.

1986 État des langues et langues de l'État au Zäre, p. 7-27.

ROOD (N.)

1958 Ngombe-Nederlands-France Woordenboek. Tervuren: Musée Royal du Congo Belge. With maps.

SAMARIN (W. J.)

1958 The phonology of Pidgin Sango. Word 14:62-70.

1961 The vocabulary of Sango. Word 17(1):16-22.

1962 Une lingua franca centrafricaine. In Symposium on multilingualism. CCTA, Publication 87. Brazzaville: Commission de coopération technique en Afrique, p. 257-265.

1966 Self-annulling prestige factors among speakers of a creole language. In Sociolinguistics: Proceedings of the UCLA sociolinguistics conference, 1964, ed. by William Bright. The Hague: Mouton \& Co. Pp. 188-213.

1967 A grammar of Sango. The Hague: Mouton \& Co. 284 p.

1971 Salient and substantive pidginization. In Pidginization and creolization of languages, ed. by Dell Hymes. Cambridge University Press, p.117-140.

1982a Colonization and pidginization on the Ubangi river. Journal of African Languages and Linguistics 4:1-42.

1982b Goals, roles, and language skills in colonizing central equatorial Africa. Anthropological Linguistics 224:410-422.

1984a The linguistic world of field colonialism. Language in Society 13:435-453.

1984b Bondjo ethnicity and colonial imagination. Canadian Journal of African Studies 18:345-365.

1984c La communication par les eaux et les mots oubanguiens. (Translation of the English text of 1984/1985.) Recherches centrafricaines. Problèmes et perspectives de la recherche historique. Table ronde: ASOM [Académie des sciences d'outre-mer], CHEAM [Centre de hautes études sur l'Afrique et l'Asie moderne], IHPOM, Paris, 
Septembre 1982. Études et documents, $\mathrm{n}^{\circ}$ 18. Aix-en-Provence: Université de Provence, Institut d'histoire des pays d'outre-mer, p. 179-239.

1984/1985 Communication by Ubangian water and word. Sprache und Geschichte in Afrika 6:309-373. See above.

1985 Plurigenesis in pidginization. Journal of Historical Linguistics and Philology 2(1/2): 100-119.

1986a The source of Sango's 'be.' Journal of Pidgin and Creole Languages 1(2):205-223.

1986 b Chinook Jargon and pidgin historiography. Revue canadienne d'anthropologie 5(1):23-34.

1987 Lingua franca. In Sociolinguistics: an International Handbook of the Science of Language and Society, vol. 1, ed. by Ulrich Ammon, Norbert Dittmar, \& Klaus J. Mattheier. Berlin \& New York: Walter de Gruyter, p. 371-374.

1988 Le comportement linguistique des colonisateurs dans le Haut Congo Français. In Dialoguer avec le Léopard. Pratiques, savoirs et actes du peuple face au politique en Afrique noire contemporaine, ed. by B. Jewsiewicki \& H. Moniot. Paris: L'Harmattan, p. 49-73.

1989a The black man's burden: African colonial labor on the Congo and Ubangi Rivers, 1880-1900. Boulder, Colorado: Westview Press.

1989b The colonial heritage of the Central African Republic: a linguistic perspective. The International Journal of African Historical Studies 22(4):697-711.

1990 The origins of Kituba and Lingala. Journal of African Languages and Linguistics 12:47-77.

TABER (Charles R.)

1965 A dictionary of Sango. Project director: W. J. Samarin. Contract with the United States Office of Education. Hartford, Connecticut: Hartford Seminary Foundation, $338 \mathrm{p}$.

1965 French loan words in Sango: a statistical analysis of incidence. M.A. thesis, Hartford Seminary Foundation. Hartford Series in Linguistics. Hartford, Connecticut: Hartford Seminary Foundation.

1966 The structure of Sango narrative. Ph.D. thesis, Hartford Seminary Foundation. Hartford: Connecticut, 248 p.

ZIGBA (Daniel Blaise)

1995 Navigation et échanges commerciaux chez les riverains du bassin supérieur de l'Oubangui (XIX ${ }^{e}$ et $\mathrm{XX}^{e}$ siècles). Nanterre, Université de Paris X. Directors: Éric de Dampierre \& Jean Boulègue. Laboratoire d'ethnologie et de sociologie comparative. 


\section{REVUE TIERS MONDE}

n 152 Tome XXXVIII Octobre - Décembre 1997

Revue trimestrielle publiée par

l'Institut d'Etude du Développement Economique et Social Université de Paris I Panthéon-Sorbonne

\section{$n^{\circ} 152$}

Régis Chavigny - Economies en transition et économies en développement : une comparaison

Pierre Huyette Mobilité et informalité : des nouvelles formes aux régulations modernes de l'emploi en Colombie

Jean-Pierre Lachaud

Laurent Parrot

Taladidia Thiombiano

StéphaneTizio

Yves-Antoine Flory

Patrick Plane

Karine Bennafla

Documentation

Michel Lelart

Débat

Frédéric Durand L'exportation du bois brut peut-elle aider à préserver les forêts tropicales? Le cas de l'Indonésie et des Philippines

Bibliographie - Analyses bibliographiques

Table des matières du tome XXXVIII, 1997

Rédaction et administration : Institut d'Etude du Développement Economique et Social 58, Bd Arago 75013 Paris - tel : 0144087307 - fax 0147078175

Abonnements et ventes : Presses Universitaires de France - Département des Revues

14, avenue du Bois de l'Epine B.P. 90, 91003 Evry Cedex - tel : 0160778205 - fax 0160792045

Prix du numero: 145 F - Abon'nements pour l'annee 1997 : France 480 F - Etranger 530 F 